\title{
Energy and the implication of residential cooling in hot climates: a case study for developing an effective solution for residential cooling energy demand in Kuwait
}

\author{
H. Al-Mutairi, J. Dewsbury \& G. F. Lane-Serff \\ School of Mechanical, Aerospace and Civil Engineering, \\ University of Manchester, UK
}

\begin{abstract}
Global energy statistics showed that oil is the most sought after energy source in the world. The economic burden on countries that are dependent on oil to produce electricity is noteworthy. Residential cooling is a significant consumer of electricity produced by oil in major oil producing countries with hot climates conditions. For this, Kuwait was selected for further analysis. By analysing official annual electricity statistics in Kuwait, residential cooling consumes $58.4 \%$ of the total delivered electrical energy at peak time on a hot summer day. Accordingly, the paper investigated orientation and grouping patterns of future houses in Kuwait to determine their impact on cooling load and electrical energy consumption. The popular DOE EnergyPlus simulation engine, through its interface with DesignBuilder Software, was used to obtain the cooling loads of the future houses. It was found that efficient orientation and grouping of houses, which is a zero cost energy conservation measure, can lead to tangible savings for future houses with approximately \$US 33 million of power system capital costs, $15 \mathrm{GWh}$ per year of electrical energy consumption and 11 kilotons per year of $\mathrm{CO}_{2}$ emissions.

Keywords: energy demand, oil, residential cooling, building simulation, houses orientation and grouping.
\end{abstract}

\section{World energy situation and consumption consequences}

The rapidly increasing use of energy in the world has caused concern about supply difficulties and serious environmental impacts. Fossil fuels (i.e., coal, oil, 


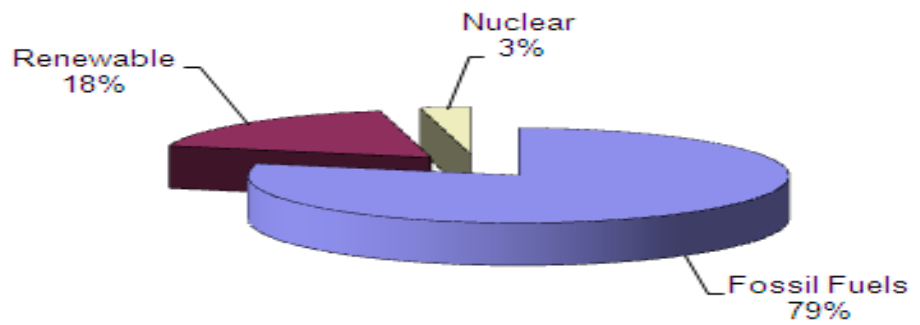

Figure 1: Global energy consumption, based on official statistics [1].

and gas) and nuclear energy are the major sources of energy, followed by renewable sources. Global energy consumption is shown in Fig. 1.

The global demand for energy generally increases as the human population, urbanization, and modernization increase. However, the high reliance on oil is notable. Official statistics show that oil is used to produce about $35 \%$ of the world energy demand [2]. It is important to acknowledge that the demand for oil will continue to increase unless drastic changes are made. Fig. 2 shows the history and projections for the demand for oil and other global energy resources in million ton [3]. From an economic point of view, the oil industry is a profitable sector for some corporations and governments, and taxes from oil are a major source of income for about 90 governments [4].

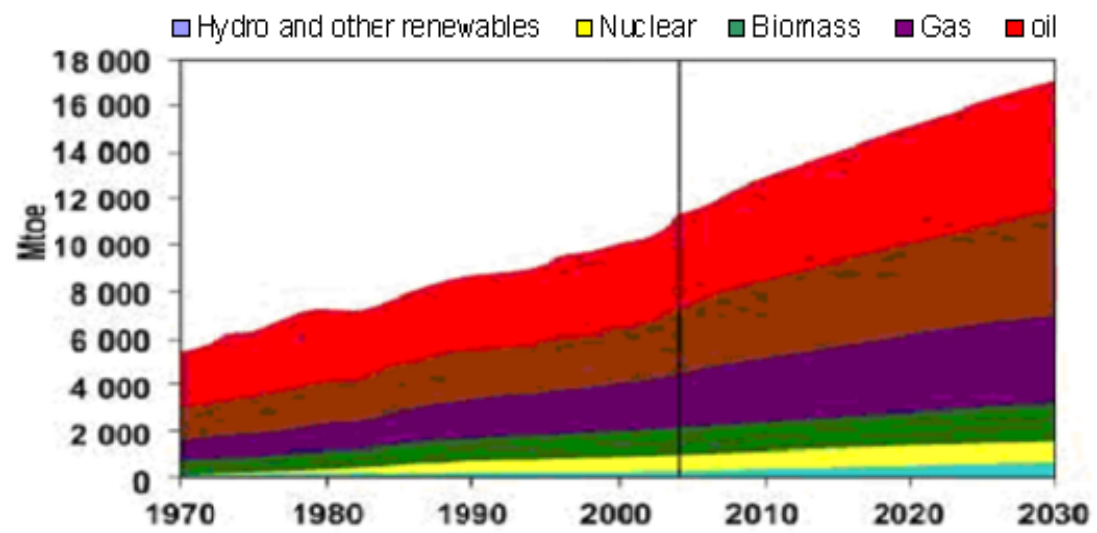

Figure 2: The history and projections for global energy resources through 2030 [3].

\section{Energy and life needs}

Modernization and improvements in the quality of life have caused the demand for energy to reach high levels. Energy, especially electricity, touches on almost all aspects of life in all developed and developing societies. For this reason, the 
paper herein gives an overview of electrical energy consumption per capita, residential electrical energy consumption in the world as a whole, and residential electrical energy consumption in five specific countries, as shown in Fig. 3. The five countries were selected based on their shares of electrical energy per capita, which is directly related to individual incomes and climate conditions, which can influence electricity consumption. Consumption per capita is the common measure of the energy demand. Per capita energy consumption varies from country to country, and, within a country, it varies from region to region, depending on the level of urbanization. Suthuye and Meyers [5] showed that the per capita energy consumption is influenced by the growth in household income, which allows people to buy devices that use more energy, such as refrigerators, water heaters, and air conditioning. Also, the consumption of energy in productive activities enables growth in income, because workers and businesses are able to use power-driven machinery, which makes them more productive.

It is clear from Fig. 3 that four countries, excluding India, are above the world average in both per capita electrical consumption and the percentage of the consumption used by the residential sector. This can be explained as being due to the variation in modernization and lifestyle between India and the other four countries. However, the residential sector share from the total electricity consumed in Saudi Arabia is significant. This is because Saudi Arabia is totally dependent on its major national income energy resources (oil and gas) to produce electricity [6]. Air conditioning is the suspected factor for the immoderate electricity consumption by the residential sector in Saudi Arabia [7]. To prove how the residential sector is contributing to the extensive use of electricity for air conditioning applications, one such country, Kuwait, was selected to undergo further analysis.

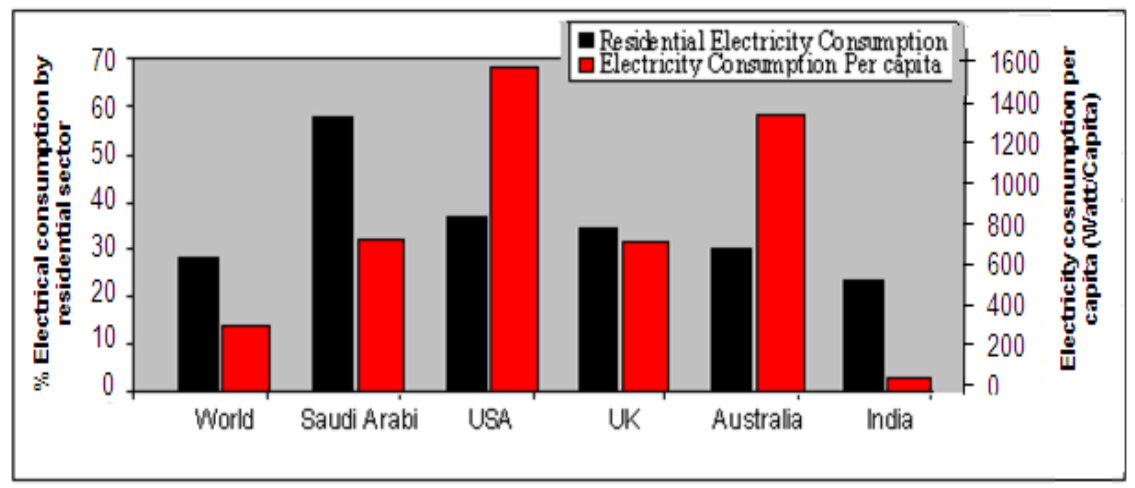

Figure 3: The percentage of residential electrical consumption nationally and per capita consumption in the world and five countries, based on official annual statistics [6]. 


\section{Hot climate country with high reliance on oil: a case study of Kuwait}

Kuwait has harsh outside climate conditions with average ambient temperature of around $45^{\circ} \mathrm{C}$ during the summer months [8], which requires the use of air conditioning systems from April through October. Buildings in Kuwait are subject to high ambient air temperatures and to strong solar radiation, which reaches as high as $940 \mathrm{~W} / \mathrm{m}^{2}$ on a horizontal surface in the summer [9]. Fig. 4 shows the variation of dry bulb temperature on a hot summer day.

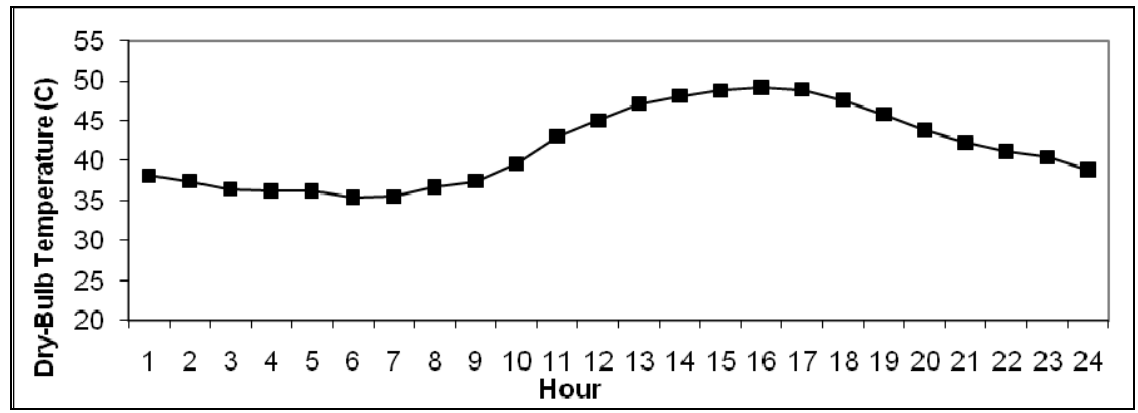

Figure 4: Variation of dry-bulb temperature on a hot summer day in Kuwait [8].

Electrical energy in Kuwait is generated by conventional steam power plants, which depend primarily on fuel oil. Continued use of the current power plant technology that depends extensively on Kuwait oil will have severe adverse impacts on the country's economy, considering that oil is the major source of national income. Darwish et al. [10] conducted a study for the local consumption of Kuwait's oil for power generation and water desalination which indicated that in about 30 years, the total oil production may not be enough to provide fresh drinking water for people and allow them to live in air-conditioned spaces.

In light of the facts about factors that affect energy consumption in the world in general, and in hot countries in particular, in this paper we have proposed a simple technique to determine the significant factor that affects electrical energy consumption in hot climates. Using Kuwait as an example, the proposed technique was used to analyze the statistics related to national annual electrical energy consumption. The first step was to obtain the maximum and minimum monthly electrical energy consumption in Kuwait using the annual electrical statistical book for the year 2006 [11], as shown in Fig. 5.

Air conditioning in the Kuwaiti residential sector is from the beginning of April to the end of October [12]. Moreover, according to our observation, no heating is required during the second half of February and March. Now, based on the maximum and minimum electrical demands obtained from Fig. 5, the estimation of the suspected electrical energy required for operating airconditioning systems during peak usage days in the summer can be made by 


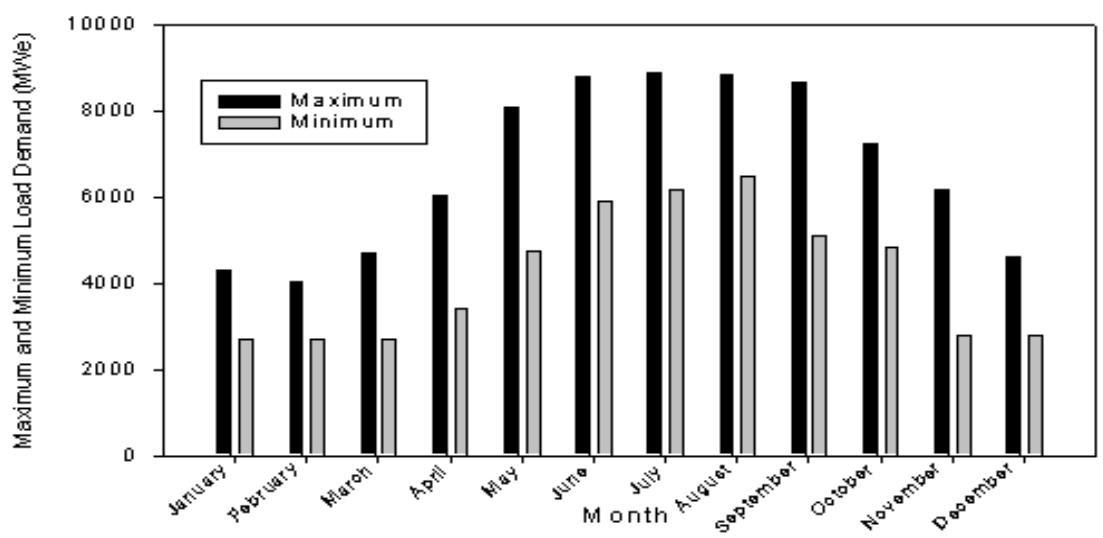

Figure 5: Monthly maximum and minimum electrical energy demand in Kuwait in 2006.

taking the difference between maximum and minimum demands during the year. According to Fig. 5, the minimum system demand was about $2710 \mathrm{MW}_{\mathrm{e}}$ at 14:00 hours on February 25, 2006 [11]. As we mentioned earlier, the lowest demand was in February because the temperature was relatively moderate and no heating or cooling systems were required during this month. Also, most of the lighting systems in the buildings and on the streets are switched off at this hour (14:00). The maximum demand was $8900 \mathrm{MW}_{\mathrm{e}}$, and it occurred at 15:30 on July 26, 2006, at which time the highest outside temperature for the year occurred [11]. Consequently, the difference between the minimum demand and the maximum demand was $6190 \mathrm{MW}_{\mathrm{e}}$, which amounts to about $69.5 \%$ of the total energy generated at the maximum demand in the year. The difference herein is expected due to the operation of air-conditioning systems in all buildings in Kuwait. Yet, to verify the share of residential sector air conditioning, we must know the percentage of residential buildings among all buildings types in Kuwait. Residential buildings represent about $84 \%$ of all buildings in Kuwait [11]. Using the percentage obtained on the national level for the energy consumption attributed to air-conditioning, i.e., $69.5 \%$, it can be said that residential airconditioners consume $58.4 \%$ of the total electrical energy delivered by power plants at peak usage time on a hot summer day in Kuwait.

\section{Proposing efficient solution for residential cooling: proper directional orientation and grouping of houses}

Directional orientation of buildings is a low or zero-cost measure that can reduce the cooling load due to solar radiation, as indicated by Harvey [13]. Several studies have suggested measures to control the energy demand resulting from residential air conditioning in Kuwait. Examples include sinking buildings into the ground by Ben Nakhi and Elshiaty [14], retrofitting energy conservation measures to old buildings by Al-Ragom [15], and exploring the cooling potential 
of earth-air heat exchangers by Al-Ajmi et al. [12]. But, no previous attempts have been made to assess the energy-saving benefits of appropriate directional orientation and grouping of houses in Kuwait. The work presented here estimates the effect on cooling load of four different arrangements for new houses, and the implications for electricity supply and $\mathrm{CO}_{2}$ emissions.

The government's Public Authority for Housing Welfare (PAHW) in Kuwait has planned to build 19568 houses during the years 2011 to 2016 [16]. The houses to be constructed are all two-storey houses with floor area of $400 \mathrm{~m}^{2}$. For this type of house, government policy allows renovation loans for owners to expand and improve their houses. The energy demand associated with the consequences of this policy is a major challenge for the country. We assume that the prevailing renovation and expansion practices associated with the government's residential loans policy will continue for future houses. These houses are built according to the Energy Code of Practice in terms of building envelope thermal resistance, the sizes of windows, the type of glazing, the power density of lighting, and the power rating for air conditioners [17]. One of the present authors conducted a short survey of renovated PAHW houses. It was found that it is normal for the occupiers to add a third storey, that the renovated houses are typically rectangular in shape, and that they are fully air conditioned using a central air-conditioning system with electrically powered direct expansion chiller. Fig. 6 shows a typical renovated house. This renovated house type is used to predict the cooling load and electrical energy requirements of future houses.

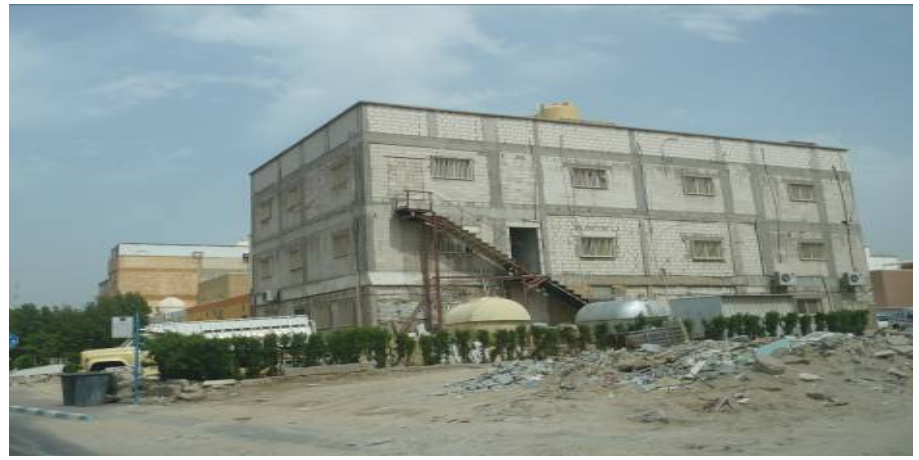

Figure 6: Example of a renovated house in Kuwait.

Typical orientation and grouping of the houses was obtained from images published on Google Earth [18]. Fig. 7 shows four cases of directional orientations and grouping: (1) single block facing east-west; (2) single block north-south; (3) double block east-west; and (4) double block north-south.

Based on Fig. 7, this study considers blocks of six houses arranged in the four common directional orientation and grouping cases, as shown in Fig. 8.

The calculation of cooling loads was done using the DesignBuilder simulation program which has an interface with the popular DOE EnergyPlus simulation 


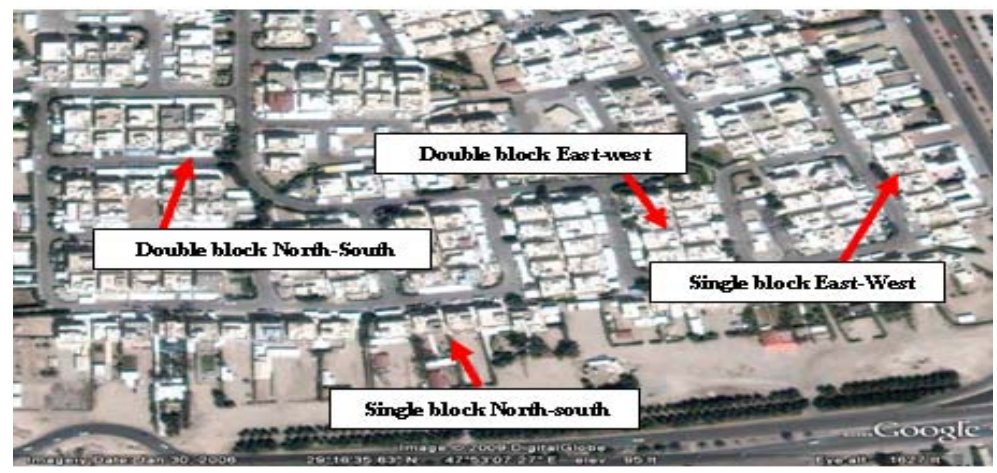

Figure 7: Common arrangements and orientations of Kuwaiti houses [18].

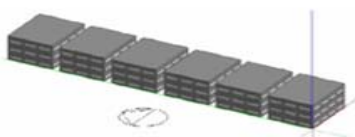

Case (1) Single Block Facing East-West

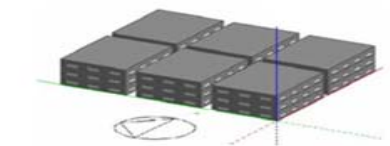

Case (3) Double Block Facing East-West

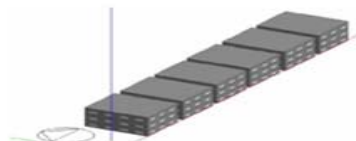

Case (2) Single Block Facing North-South

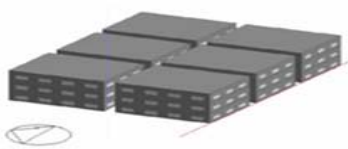

Case (4) Double Block Facing North-South

Figure 8: Houses arrangements and orientations used in this study.

engine [19]. DesignBuilder successfully passed the Building Thermal Envelope and Fabric Load Tests established by an ANSI/ASHRAE Standard [20]. A key input in cooling load calculations is the climate data for the area where the building is or will be built. DesignBuilder building simulation software provides ready access to official hourly weather files for 4429 locations in the world, including Kuwait [19]. The characteristics of the typical renovated house in Kuwait and the input data pertinent to the simulation are listed in Table 1.

The specifications presented in Table 1 were taken from the Energy Code of Practice for houses in Kuwait, and the operation schedules for the lighting, internal blinds and equipment loads were based on our observations of a number of typical Kuwaiti houses. The same simulation input data was used for all the houses in order to measure the sensitivity of the cooling load to their directional orientation and grouping. Joseph and Sam [21] indicated that fixing all the input data except the one parameter to be analyzed is referred to as sensitivity analysis; this technique can help building designers and decision makers evaluate the thermal design of a building. The differences in simulation results can be attributed to changing the studied parameter, as recommended by Spitler et al. [22]. 
Table 1: $\quad$ Simulation input data for each house.

\begin{tabular}{|c|c|}
\hline Parameter & Detail \\
\hline Plan shape & Rectangular \\
\hline Number of storeys & 3 \\
\hline Floor-to-floor height & $4 \mathrm{~m}$ \\
\hline Floor dimensions & $18 \mathrm{~m} \times 22 \mathrm{~m}$ (approximately $\left.400 \mathrm{~m}^{2}\right)$ \\
\hline Wall area of one floor & $315.4 \mathrm{~m}^{2}$, internal wall area \\
\hline Window area & $30 \%$ of the wall area, uniformly distributed \\
\hline Type of window glass & $\begin{array}{l}\text { - 6-mm thick, double glazed, clear and reflective glass } \\
\text { - U-value }\left(3.38 \mathrm{~W} / \mathrm{m}^{2}-{ }^{\circ} \mathrm{K}\right)\end{array}$ \\
\hline Window blinds & Internal blind closed daily between 12 noon - 11 p.m. \\
\hline Wall U-value & $0.568 \mathrm{~W} / \mathrm{m}^{2}-^{\circ} \mathrm{K}$ \\
\hline Roof U-value & $0.397 \mathrm{~W} / \mathrm{m}^{2}-{ }^{\circ} \mathrm{K}$ \\
\hline People load & 10 persons; $110 \mathrm{Watt} /$ person \\
\hline Lighting load & $10 \mathrm{~W} / \mathrm{m}^{2}$, fluorescent lights \\
\hline Lighting schedule & 12 noon - 11 p.m. daily with a diversity factor of $70 \%$ \\
\hline Equipment load & $12 \mathrm{~W} / \mathrm{m}^{2}$ for ground floor and $5 \mathrm{~W} / \mathrm{m}^{2}$ for upper floors \\
\hline Equipment schedule & $\begin{array}{l}\text { - Ground floor: Weekdays: } 7 \text { a.m. }-9 \text { a.m. and } 4 \text { p.m. } \\
-11 \text { p.m.; Weekends: } 7 \text { a.m. }-11 \text { p.m. } \\
\text { - Upper Floor: } 4 \text { p.m. }-11 \text { p.m. daily }\end{array}$ \\
\hline Infiltration & 0.5 air change per hour \\
\hline Thermostat setting & $24^{\circ} \mathrm{C}$ and $50 \% \mathrm{RH}$ \\
\hline
\end{tabular}

To estimate the annual electrical energy consumption ( $E_{\text {annual }}$ ), the annual cooling load $\left(\mathrm{Q}_{\text {annual }}\right)$ was multiplied by the allowable power rating (PR) for residential air conditioning from the Energy Code of Practice, i.e. $1.7 \mathrm{~kW} / \mathrm{RT}$ or $0.4834 \mathrm{kWe} / \mathrm{kWr}(1 \mathrm{RT}=$ refrigeration ton, $1 \mathrm{RT}=3.517 \mathrm{~kW}$ refrigeration $)$. This power rating is for the direct-expansion air conditioning systems that are commonly used in the residential sector in Kuwait. Annual electrical energy consumption was obtained from the following expression:

$$
\mathrm{E}_{\text {annual }}=\mathrm{Q}_{\text {annual }} * \mathrm{PR}
$$

Hajiah [23] indicated that conventional power plants in Kuwait emit $0.72 \mathrm{~kg}$ of $\mathrm{CO}_{2}$ for every $\mathrm{kWh}$ of electricity produced. The amount of annual electrical energy was used to estimate the associated $\mathrm{CO}_{2}$ as follows:

$$
\mathrm{CO}_{2} \text { Emissions }=\mathrm{E}_{\text {annual }} * 0.72
$$

Estimated savings in electrical energy production cost was based on the net cost to the government, which is \$ US 0.09/kWh [24]:

$$
\text { Electricity Production Cost }=\mathrm{E}_{\text {annual }} * \text { \$US 0.09/kWh }
$$

Electrical supply capital cost was estimated based on the peak cooling load (PL) for each case. The peak cooling load was multiplied by the allowed power 
rating (PR) to convert it to electrical load, then this was multiplied by the capital cost of conventional power plant in Kuwait, which is $\$$ US $1500 / \mathrm{kW}_{\mathrm{e}}$ [25]. The calculation was performed as shown:

$$
\text { Electrical Supply Capital Cost }=\text { PL* PR * } \$ \text { US 1500/kW }
$$

The 19568 future PAHW houses are equivalent to approximately 3621 blocks of six houses. The results from each simulation case were multiplied by 3261 to estimate the results for the future houses.

The peak cooling load would give the first indication about any promising alternative for the four cases studied. The simulation results for the four simulated blocks showed that the single block east-west case, case (1), has the largest peak cooling load of the four cases. The cooling-load profile for the four simulated cases during the peak day, as a percentage of the peak cooling load for the single block east-west case, case (1), is shown in Fig. 9.

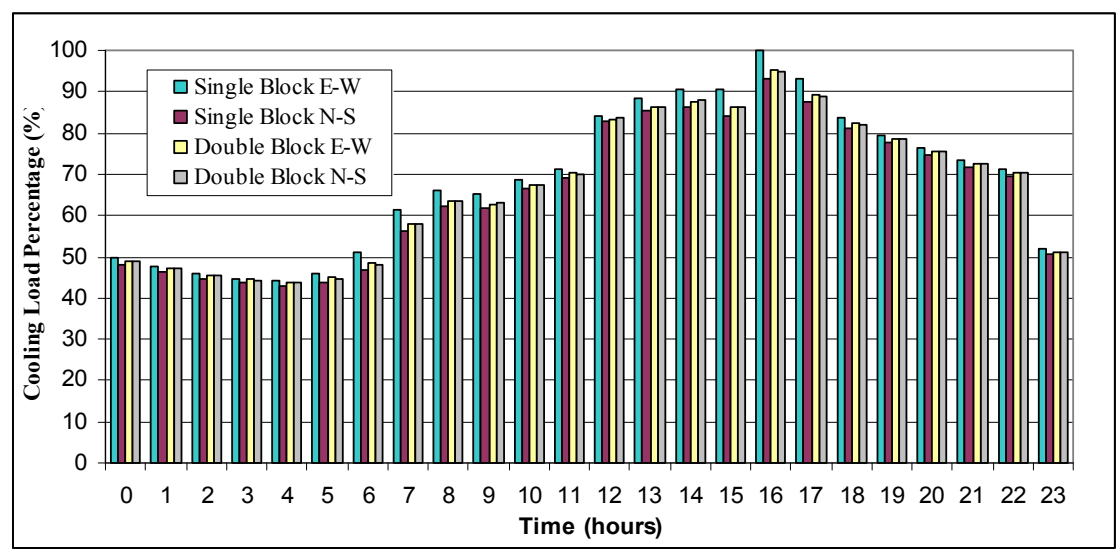

Figure 9: Peak day cooling load profile for the four simulated cases as a percentage of peak load that resulted for case (1).

As can be seen in Fig. 9, the single block east-west case has the largest peak cooling load. This is followed by the double block east-west case, i.e., case (3). The north-south cases have lower cooling load values compared to the east-west cases, and the lowest among the four cases is the single block north-south case, i.e., case (2). The largest peak cooling load is $6.6 \%$ greater than the lowest, which is a fairly small difference. The peak cooling load is highest for the single block facing east-west, because it has a large solar gain on its west facade in the afternoon, when the outside air temperature is high.

The results obtained by equations (1) to (4) for the four cases are listed in Table 2. For better understanding for the comparison, Table 3 shows the anticipated savings from each case. The savings shown compared to the average of the four cases (this is equivalent to assuming that the future houses will be distributed equally between the four orientations and grouping arrangements). 
Table 2: $\quad$ Results for the 19568 houses.

\begin{tabular}{|c|c|c|c|c|c|c|}
\hline Type & Unit & Case 1 & Case 2 & Case 3 & Case 4 & Average \\
\hline $\begin{array}{c}\text { Peak electrical } \\
\text { load }\end{array}$ & $\mathrm{MW}_{\mathrm{e}}$ & 693 & 645 & 670 & 659 & 667 \\
\hline $\begin{array}{c}\text { Electrical } \\
\text { supply capital } \\
\text { cost }\end{array}$ & $\begin{array}{c}\$ \mathrm{US} \\
\text { million }\end{array}$ & 1,040 & 967 & 1,004 & 988 & 1,000 \\
\hline $\begin{array}{c}\text { Annual } \\
\text { electrical } \\
\text { energy }\end{array}$ & $\mathrm{GWh}$ & 1,593 & 1,554 & 1,565 & 1,563 & $1,568.7$ \\
\hline $\begin{array}{c}\text { Annual } \\
\text { generation cost } \\
\text { to government }\end{array}$ & $\begin{array}{c}\text { \$US } \\
\text { million } \\
\text { per year }\end{array}$ & 143.4 & 139.8 & 140.7 & 140.6 & 141.2 \\
\hline $\begin{array}{c}\text { Annual CO } \\
\text { emissions }\end{array}$ & $\begin{array}{c}\text { kilotons } \\
\text { per year }\end{array}$ & 1,150 & 1,120 & 1,130 & 1,125 & 1,131 \\
\hline
\end{tabular}

Table 3: Anticipated savings for the future 19568 houses based on the results obtained from Table 2 .

\begin{tabular}{|c|c|c|c|c|c|}
\hline Saving & Unit & Case 1 & Case 2 & Case 3 & Case 4 \\
\hline $\begin{array}{c}\text { Electrical supply } \\
\text { capital cost }\end{array}$ & \$ US million & -40 & 33 & -4 & 12 \\
\hline $\begin{array}{c}\text { Annual electrical } \\
\text { energy }\end{array}$ & $\mathrm{GWh}_{\mathrm{e}} /$ Year & -24.3 & 15 & 3.7 & 5.7 \\
\hline $\begin{array}{c}\text { Annual electrical } \\
\text { generation cost to } \\
\text { government } \\
\text { million/year }\end{array}$ & -2.2 & 1.35 & 0.5 & 0.6 \\
\hline $\begin{array}{c}\text { RUS } \\
\text { annual CO } 2 \\
\text { emissions }\end{array}$ & $\begin{array}{c}\text { kilotons per } \\
\text { year }\end{array}$ & -19 & 11 & 1.76 & 4.1 \\
\hline
\end{tabular}

Note: the (-) sign indicates increased costs and emissions.

Table 4 shows twenty-year projected savings for each case, excluding the single block east-west case due to the reasons specified earlier. The estimated savings presented in Table 4 are based on the savings resulted from the average of the four cases presented earlier in Table 3 .

As can be seen from Table 4, the single block north-south case would achieve significant savings among other cases. Although case 3 did not achieve saving in the electrical energy capital cost, it was introduced in the projected savings because it achieved savings in the annual electrical energy consumption. 
Table 4: Twenty-year projection of the expected savings for the future 19568 houses.

\begin{tabular}{|l|c|c|c|c|}
\hline Case & $\begin{array}{c}\text { Savings in } \\
\text { Electrical } \\
\text { Supply Capital } \\
\text { Cost (million \$ } \\
\text { US }\end{array}$ & $\begin{array}{c}\text { Savings in } \\
\text { Electricity } \\
\text { Production Cost } \\
\text { in (million \$ US) }\end{array}$ & $\begin{array}{c}\text { Total } \\
\text { Savings } \\
\text { (million \$ } \\
\text { US) }\end{array}$ & $\begin{array}{c}\mathrm{CO}_{2} \\
\text { Equivalent } \\
\text { to Seasonal } \\
\text { Electricity } \\
\text { Savings } \\
\text { (kiloton) }\end{array}$ \\
\hline Case 2 & 33 & 27 & 60 & 222 \\
\hline Case 3 & -4 & 10 & 6 & 35.2 \\
\hline Case 4 & 12 & 12 & 24 & 82 \\
\hline
\end{tabular}

Note: the (-) sign indicates increased costs.

\section{Conclusion}

Fossil fuels, especially oil, are an important global energy resource. The extensive usage of global energy resources has negative impacts on all aspects of life. The paper indicated that there is a direct relationship between residential energy consumption and consumption per capita. Hot weather was also found to be a significant factor for energy consumption in countries that have harsh summer conditions and totally dependent on valuable energy resources to generate electricity. In conjunction with these facts, Kuwait was selected for additional analysis of its electrical energy usage. The findings proved that residential cooling is the significant factor for electricity in Kuwait. The authors proposed a unified orientation and grouping style for future houses as a zero cost energy conservation measure. The proposed orientation and grouping style of houses can reduce solar gain; which therefore and can lead to significant savings in energy and $\mathrm{CO}_{2}$ emissions.

\section{References}

[1] Renewables; Renewable Energy Network for the first twenty one century, Global Status Report, 2007.

[2] International Energy Administration (IEA); Key World Energy Statistics, 2007.

[3] International Energy Administration (IEA), World Annual Statistics, 2006

[4] Dara O'Rourke and Sarah Connolly; Annual Reviews Environ. Resources, Volume 28, pp. 587-617, 2003.

[5] Suthuye and Meyers; Energy use in the cities of the developed countries. Annual Reviews. Emrgjs, volume10, pp.109-33, 1985.

[6] International Energy Administration (IEA), World Annual Statistics, 2006.

[7] I. Dincer, M. M. Hussain and I. Al-Zaharnah, Analysis of sectoral energy and exergy use of Saudi Arabia, International journal of energy research, Int. J. Energy Res. 2004; 28:205-243 (DOI: 10.1002/er.962). 
[8] Kuwait International Airport, Climatological summaries year1962-1982, Meteorological Department climatological division; State of Kuwait, 1983.

[9] T.R. Allison, Heat gains in Kuwait Buildings, a simplified Code, Kuwait Institute for Scientific Research, (KISR) -PPI/110 ENG-PT-G-7931, 1979.

[10] Darwish M.A., Al-Awadhib and A.M. Darwish, Energy and water in Kuwait Part I. A sustainability view point, Desalination 225 (2008) 341355.

[11] Ministry of Electricity and Water (MEW); Statistical year book, 2007.

[12] Al-Ajmi, F., Loveday, L.D., Hanby, V., 2006. The cooling potential of earth-air heat exchangers for domestic buildings in a desert climate, Building and Environment 41, 235-244.

[13] Harvey Harvey, L.D.D. 2006. A Handbook on Low-Energy Buildings and District-Energy Systems: Fundamentals, Techniques and Examples. EarthScan, London, 701 pages.

[14] Ben-Nakhi, A.E., and El Shiaty, R.M., 2009. Thermal impact of sinking residential buildings in hot regions- Kuwait as a case study, Energy Technology and Policy Vol.7 No.1, 3-17.

[15] Al-Ragom, F., 2003. Retrofitting residential buildings in hot and arid climates, Energy Conservation and Management 44, 2309-2319.

[16] PAWE 2008 PAHW, Public Authority for Housing Welfare, 2010. Five year strategic plan (2011-2016), new residential projects, Kuwait.

[17] MEW, 1983. Ministry of Electricity and Water. Energy Code of Practice, Buildings characteristics, Kuwait.

[18] Google earth, 2009. www.earth.google.com , Image(C2009 Digital Glob, image date Jan. 2006, accessed in 4-5-2009.

[19] DesignBuilder Documentation, 2006. DesignBuilder User Manual, Version 1.2, DesignBuilder Software Limited, UK.

[20] ASHRAE, 2006. Building Thermal Envelope and Fabric Test from ANSI/ASHRAE Standard, ASHRAE 140 Envelop Test, www.cetteg.fr/fichiers/ansi_ashrae.pdf

[21] Joseph, C.L. and Sam, C.M., 1996. Sensitivity analysis of energy performance of office, Buildings and Environment 31, 27-39.

[22] Spitler, J.D., Fisher, D.E., Zietlow, D.C., 1989. A primer on the use of influence coefficients in building simulation, Proceedings of Building Simulation'89 Conference, pp. 299-304, Vancouver.

[23] Hajiah, A. Energy conservation program in Kuwait, a local prospective, proceedings of fifteenth symposium on improving building systems in hot and humid climates, Orlando, FL, July 24-26, 2006.

[24] Al-Mutairi, A., 2009. Manager Technical Office in Ministry of Electricity and Water, Kuwait, Private Communication.

[25] Darwish, M. A., 2008. Building air conditioning system using fuel cell: Case study for Kuwait, Applied Thermal Engineering 27, 2869-2876. 